\title{
Influence of feeding plasticity on the fitness of small Neotropical characids
}

\author{
Leandro Fabrício Fiori', Gustavo Henrique Zaia Alves', Norma Segatti Hahn,2 \& Evanilde Benedito ${ }^{1,2,3}$

\begin{abstract}
1. Programa de Pós-Graduação em Ecologia de Ambientes Aquáticos Continentais (PEA)/Núcleo de Pesquisas em Limnologia, Ictiologia e Aquicultura (Nupélia) da Universidade Estadual de Maringá (UEM). Av. Colombo, 5790, 87020-900 Maringá, Brazil.

2. Departamento de Biologia, Universidade Estadual de Maringá (UEM). Av. Colombo, 5790, 87020-900 Maringá, Brazil.
\end{abstract} \\ 3. Programa de Pós-Graduação em Biologia Comparada (PGB)/Universidade Estadual de Maringá (UEM). Av. Colombo, 5790, 87020-900, Maringá, Brazil.
}

Received 4 June 2015

Accepted 2 May 2016

DOI: $10.1590 / 1678-4766 e 2016006$

\begin{abstract}
This study investigated the diet of four characids [Hyphessobrycon eques (Steindachner, 1882), Odontostilbe pequira (Steindachner, 1882), Psellogrammus kennedyi (Eigenmann, 1903) and Serrapinnus calliurus (Boulenger, 1900)] coexisting in two lagoons and checked for possible spatial differences and the influence on population fitness. The main goal was check if these species show better fitness according to the nutritional value of the food resource consumed. In this way, it is expected that the species show improved nutritional conditions (evidenced by the relative condition factor) when foraging for items of animal origin, and the reverse is expected when consuming items of plant origin and detritus. Sampling was conducted in August 2011. The diet was evaluated by analyzing contents and calculating the relative condition factor for each sampled individual, obtaining a mean value for each population. Species exhibited high food plasticity; H. eques and $P$. kennedyi altered most their diets from a lagoon to another. Despite these variations, the condition factor showed no significant spatial variation for any species. The results indicated that these species have physiological adaptations that allow them to obtain the maximum energy from food, even if it has low nutritional value, or that fish can compensate for the consumption of low nutritional food by increasing the consumption rate. Thus, regardless of the type of resources consumed, these have met the metabolic needs of the fish in the studied lagoons.
\end{abstract}

KEYWORDS. Fishes, diet, condition factor, Pantanal, lagoons.

RESUMO. Influência da plasticidade alimentar no fitness de pequenos caracídeos neotropicais. Este estudo investigou a dieta de quatro caracídeos [Hyphessobrycon eques (Steindachner, 1882), Odontostilbe pequira (Steindachner, 1882), Psellogrammus kennedyi (Eigenmann, 1903) e Serrapinnus calliurus (Boulenger, 1900)], que coexistem em duas lagoas, e verificaram-se possíveis diferenças espaciais no fitness dessas populações. O objetivo principal foi analisar se essas espécies demonstram melhor fitness de acordo com o valor nutricional do recurso consumido. Desta forma, espera-se que as espécies demonstrem melhores condições nutricionais (demonstrado pelo fator de condição relativo) durante o forrageamento de itens de origem animal, assim como o contrario é esperado ao consumir itens de origem vegetal e detritos. A amostragem foi realizada em agosto de 2011 . A dieta foi avaliada através da análise do conteúdo estomacal e o fator de condição relativo foi calculado para cada indivíduo amostrado, obtendo-se um valor médio para cada população. As espécies exibiram elevada plasticidade alimentar; $H$. eques e $P$. kennedyi alteraram a maioria dos itens alimentares de suas dietas entre as lagoas estudadas. Apesar destas variações, o fator de condição não variou espacialmente para qualquer espécie. Os resultados indicam que estas espécies possuem adaptações fisiológicas que lhes permitem obter o máximo de energia a partir do alimento, mesmo que tenha baixo valor nutricional, ou que o peixe pode compensar o consumo de alimentos com baixo valor nutricional, aumentando a taxa de consumo. Assim, independentemente do tipo de recursos consumidos, estes recursos cumpriram as necessidades metabólicas dos peixes nas lagoas estudadas.

PALAVRAS-CHAVE. Peixes, dieta, fator de condição, Pantanal, lagoas.

Fish use a wide array of food resources available in the environment (SCHNEIDER et al., 2011) and are known to occupy all trophic levels, more than any other vertebrate group (Wootton, 1990). Members of the family Characidae have all types of feeding habits and can change them depending on the environment and spatial and seasonal fluctuations (e.g. Barreto \& Aranha, 2006; Pelicice \& Agostinho, 2006; Dias \& FialHo, 2009; TÓFOLi et al., 2010; Alves et al., 2011; MANNA et al., 2012; WolfF et al., 2013). This behavior is known as trophic flexibility or plasticity (WооттоN, 1990; Lowe-MCCONNELL, 1999) that allows different species to coexist by reducing the interspecific competition (Brown, 1995). However, due to this ability, many fish can change their diets in the presence of potential competitors and/or predators and even under shortage of preferred food and, forced to consume low nutritional value food.

The optimal foraging models predict that animals will always choose higher energy foods with a minimum of effort, 
so that the cost/benefit relationship is balanced (STEPHENS \& Krebs, 1986; Gerking, 1994). However, optimal food items may not be available in nature, making the diet a result from the interaction between food preference and food availability in the environment (WoOTTON, 1990). Factors such as size, morphology and prey behavior influence this cost-benefit relationship (STEPHENS \& KREBS, 1986). Thus, the consumption of non-preferred and lower energetic food items can change the fitness of the population (CRUZ-RIVERA \& HAY, 2000).

In this way, investigating the diet and feeding tactics of fish species provide important information about the population structure (HAHN et al., 1997; BARRETO \& ARANHA, 2006; SPECZIÁr \& ERós, 2014). Furthermore, these results combined with the condition factor, which indicates the degree of well-being and reflects the recent feeding conditions (Le Cren, 1951; VAZZOLER, 1996), point out whether feeding plasticity is disadvantageous, especially when considering spatial variation in the diet of a population. Bowen et al. (1995), also mentioning other authors, argue that invertebrate prey are high in both protein and energy while plant tissues are lower in energy, since most species use lower energy carbohydrates for both structural elements and energy storage. These differences in protein and energy contents are ecologically significant inasmuch as consumer growth rate is expected to be directly proportional to nutrient level both within and among the ranges for food categories. FERREIRA et al. (2012), also comment that the consumption of aquatic insects being energetically advantageous in comparison to detritus.

The characids Hyphessobrycon eques (Steindachner, 1882), Odontostilbe pequira (Steindachner, 1882), Psellogrammus kennedyi (Eigenmann, 1903) and Serrapinnus calliurus (Boulenger, 1900) occur simultaneously in lagoons associated with the Miranda River, Pantanal of Mato Grosso do Sul State, and commonly show variations in their diets (e.g. Carvalho \& Del-Claro, 2004; Crippa et al., 2009; Ximenes et al., 2011; Alves et al., 2011). Because these species co-occur and show high feeding plasticity, they represent a good model to investigate how changes in food quality (low and high energy) maintain these populations.

Although the plasticity in fish diet is relatively well known, its influence on the fitness of the populations remains poorly understood. Given the above, through the analysis of stomach contents, we investigated possible spatial variations in the diet of each of these species, considering two similar lagoons. In addition, we calculated the condition factor to determine whether changes in diet reflect on the welfare of fish and consequently the fitness of these populations. The main goal was check if these species have better nutritional status according to the energy content of the food consumed (Bowen et al., 1995). Thus, it is expected that the species have improved nutritional conditions when foraging for items of animal origin and the reverse is expected when consuming items of plant origin and detritus.

\section{MATERIAL AND METHODS}

Study area. The Miranda River is located in the Pantanal of Mato Grosso do Sul State, starts in the Maracaju mountain and partially drains limestone areas of the Bodoquena mountain. The drainage area has $47,000 \mathrm{~km}^{2}$ (EMBRAPA, 1991). This tributary is localized downstream of the city of Miranda and receives the waters of the Salobra River. From that point, the floodplain is spatially extended to the right, running through several meanders and undergoing extensive ranges of forests, crossing the Pantanal, receiving reflux water and other tributaries, as the Vermelho River, which contribute with water through small channels in the events of large floods (EMBRAPA, 1991).

Two sampling sites were established in two lagoons called A (19 $35^{\prime} 00.4^{\prime \prime} \mathrm{S}$ and $\left.056^{\circ} 59^{\prime} 22.1^{\prime \prime} \mathrm{W}\right)$ and B (19 $32^{\prime} 09.7^{\prime \prime}$ S and $\left.57^{\circ} 03^{\prime} 03.3^{\prime \prime} \mathrm{W}\right)$, belonging to the Miranda River floodplain (Fig. 1). Samplings were conducted in the low water period, in which there is low connectivity of the lagoons with the main river.

Sampling and data analysis. Fish were collected in August 2011, using trawls nets 20 meter long $(1 \mathrm{~cm}$ mesh size between opposite knots), fixed in $10 \%$ formalin and identified according to BRITISKI et al. (2007). Each specimen was measured (standard length, $\mathrm{cm}$ ), weighed (total weight, g), and gutted; stomachs containing food were fixed in $4 \%$ formaldehyde. Voucher specimens of fish species caught and used in this study are deposited in the fish collection of the Núcleo de Pesquisas em Limnologia, Ictiologia e Aquicultura (Nupélia/UEM) (H. eques: NUP 12609; O. pequira: NUP 12644; P. kennedyi: NUP 12608; S.calliurus: NUP 12647).

Stomach content was analyzed under stereo and optical microscopes. Food items were identified to the lowest taxonomic level using specific literature.

The quality and quantity of food consumed by fish was evaluated by the volumetric $(\% \mathrm{~V})$ and occurrence $(\% \mathrm{O})$ methods (Hyslop, 1980). The values for each food item were combined in the Feeding Index (\%IA $i$ ) (KAWAKAMI \& VAzZOLER, 1980) using the formula: $\mathrm{IAi}=\% \mathrm{Fi} * \% \mathrm{Pi} /(\% \mathrm{Fi} *$ $\% \mathrm{Pi}) * 100$, where: $i=$ food item; $\mathrm{F}=$ occurrence frequency (\%) of the item $i$ in the diet; $\mathrm{V}=$ volumetric frequency (\%) of the item $i$ in the diet.

The occurrence frequency $(\% \mathrm{Fi})$ was calculated by recording the number of fish in which each item occurred, obtaining the percentage in relation to the total stomachs with food. For the volumetric frequency, the volume of each item was obtained by the percentage in relation to the total value of every stomach contents. The volume was obtained through gridded dish, where the volume was obtained in $\mathrm{mm}^{3}$ and later transformed into ml (HeLlaWel \& ABEL, 1971).

To check for significant difference in the diet of fish between the lagoons, a Multi-Response Permutation Procedure (MRPP) was used. This is a non-parametric multivariate method used to test for differences between predefined groups (ZIMmERMAN et al., 1985). The original matrix was transformed into a dissimilarity matrix by the Bray-Curtis method, and the significance of the null 


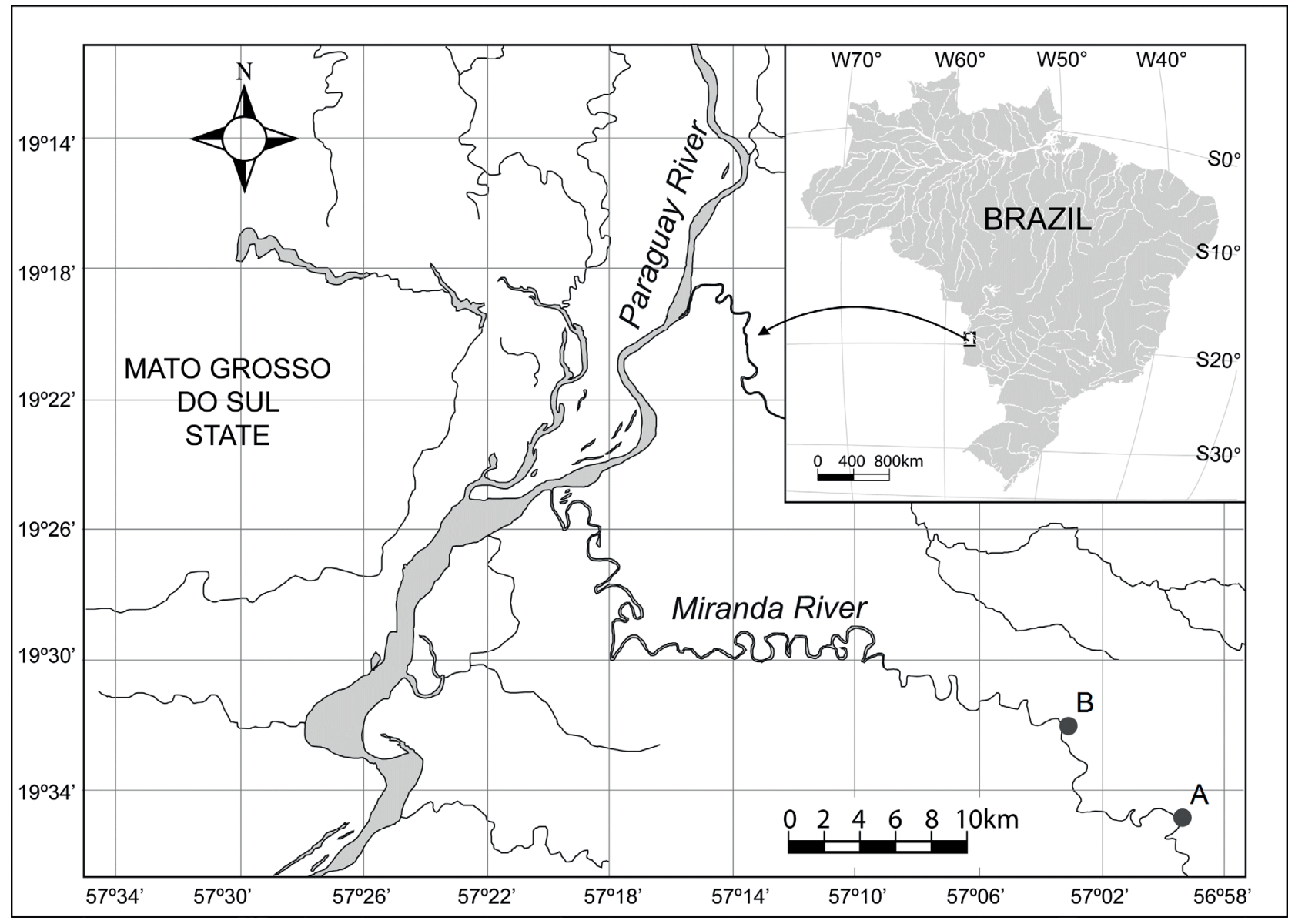

Fig. 1. Study area in the Pantanal of Mato Grosso do Sul State, Brazil. A and B indicate the sampling sites in lagoons associated with the Miranda River.

hypothesis was tested by a randomization procedure with 1000 permutations. The analyses were run using the statistical software PC-Ord ${ }^{\circledR} 4.0$ (MCCunE \& MEFFord, 1999).

Values of total weight (Wt) and standard length (Ls) of each individual were fitted to the $\mathrm{Wt} / \mathrm{Ls}$ curve $(\mathrm{Wt}=$ $a . \mathrm{Lt} b)$, and the values of the regression coefficients $a$ and $b$ was estimated. These coefficients were used to calculate the expected values of weight (We) using the equation: We $=a$.Lt $b$. Then, we calculated the relative condition factor $\mathrm{Kn})$ for each individual, which corresponds to the ratio between observed and expected weight for a given length $(\mathrm{Kn}=\mathrm{Wt} / \mathrm{We})(\mathrm{Le}$ Cren, 1951). We used the nonparametric Mann-Whitney U test at 5\% level to test the differences in the values of the relative condition factor for each species in the sampled lagoons. Analyses were performed in Statistica 7.1 ${ }^{\circledR}$ (Statsoft, 2005).

\section{RESULTS}

The analysis of 370 stomach contents of Hyphessobrycon eques, Odontostilbe pequira, Psellogrammus kennedyi and Serrapinnus calliurus indicated that these species consumed mainly food of autochthonous origin. Diets consisted mainly of benthic organisms and detritus, regardless of the lagoon. Was observed a very low consumption of terrestrial invertebrates (Fig. 2).
Comparing each population considering the lagoon, differences were found in the main food consumed $(>50 \%$ IAi), however, these changes were more evident for $H$. eques and $P$. kennedyi. The first consumed detritus and scales in the lagoon A and chironomids in the lagoon $\mathrm{B}$, while the second species consumed filamentous algae (Zygnematacea) in the lagoon A and chironomids in the lagoon B (Tab. I). Odontostilbe pequira and S. calliurus consumed primarily algae and detritus in both lagoons, demonstrating slight spatial changes in their diets (Tab. I).

The diet of the species was modified according to the environment considered. Such differences were indicated by the multi-response permutation procedure (MRPP) (MRPP) (H. eques: $\mathrm{A}=0.224 ; \mathrm{p}<0.005-O$. pequira: $\mathrm{A}=0.170 ; \mathrm{p}$ $<0.005-$ P. kenedyi: $\mathrm{A}=0.112 ; \mathrm{p}<0.005-$ S. calliurus: A $=0.153 ; \mathrm{p}<0.005)$.

Values of the relative condition factor were not significantly different $(p>0.05)$ between the lagoons (Tab. II).

\section{DISCUSSION}

The four species studied are small-sized fish ranging from 4.0 to $6.0 \mathrm{~cm}$ in the adult stage, what characterizes them as foragers. They are ecologically important species, representing a link in food chains and a part of the diet of intermediate and top predators (CORRÊA et al., 2009). Small 


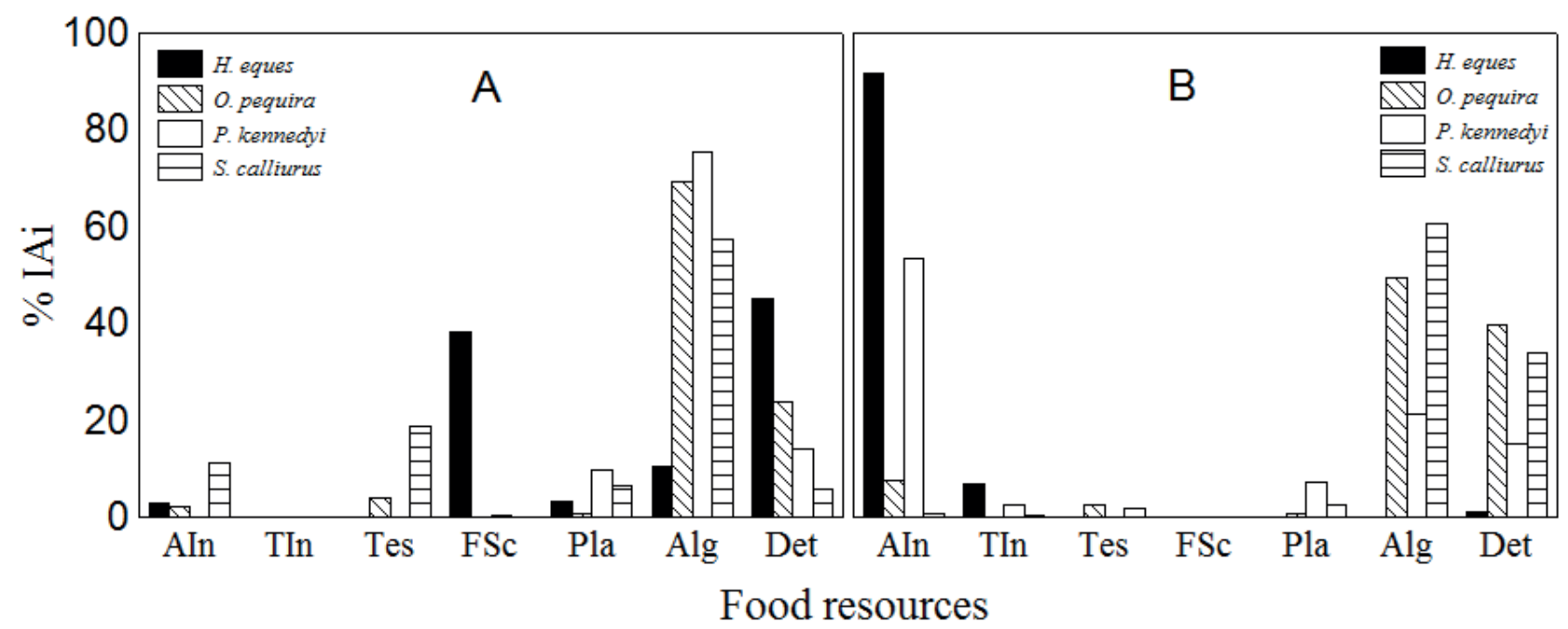

Fig. 2. Food resources (\% IAi) consumed by Hyphessobrycon eques, Odontostilbe pequira, Psellogrammus kennedyi and Serrapinnus calliurus, in the lagoons A and B (Ain, aquatic invertebrates; Tin, terrestrial invertebrates; Tes, Testacea; FSc, fish scale; Pla, plant; Alg, algae; Det, detritus).

Tab. I. Food items consumed by Hyphessobrycon eques (He), Odontostilbe pequira (Op), Psellogrammus kennedyi (Pk) and Serrapinnus calliurus (Sc) (values are the Feeding Index, \% IAi), in the lagoons A and B associated with the Miranda River (L, larvae; P, pupae; F, filamentous; U, unicellular). Numbers in bold add up values $>50 \%$.

\begin{tabular}{|c|c|c|c|c|c|c|c|c|}
\hline \multirow{2}{*}{ Resources/items } & \multicolumn{4}{|c|}{ Lagoon A } & \multicolumn{4}{|c|}{ Lagoon B } \\
\hline & $\mathrm{He}$ & $O p$ & $P k$ & Sc & $\mathrm{He}$ & $O p$ & $P k$ & Sc \\
\hline \multicolumn{9}{|l|}{ Aquatic inv. } \\
\hline Chiromomidae $(\mathrm{L}+\mathrm{P})$ & 2.83 & 0.73 & & 11.25 & 84.42 & 2.19 & 53.5 & 0.65 \\
\hline Acarina & 0.08 & & & & 0.32 & & 0.03 & \\
\hline Ceratopogonidae (L) & & & & & 0.19 & & 0.01 & \\
\hline Copepoda & & 0.01 & & & 5.72 & & 0.01 & \\
\hline Coleoptera & & 0.04 & & & & & & \\
\hline Rotifera & & 1.29 & & & & 5.28 & & \\
\hline Others & & 0.01 & & & 1.08 & 0.03 & & 0.01 \\
\hline \multicolumn{9}{|l|}{ Terrestrial inv. } \\
\hline Hemiptera & & & & & 6.66 & & 1.21 & \\
\hline Araneae & & & & & & & 0.05 & \\
\hline Remains & 0.02 & & 0.01 & & 0.21 & & 1.36 & 0.32 \\
\hline Testacea & 0.02 & 3.99 & 0.05 & 18.75 & 0.17 & 2.48 & 0.04 & 1.82 \\
\hline Fish scales & 38.1 & 0.03 & 0.51 & & 0.01 & 0.02 & 0.01 & 0.01 \\
\hline \multicolumn{9}{|l|}{ Algae } \\
\hline Zygnemataceae (F) & 0.9 & 11.7 & 52.2 & 6.65 & & 5.74 & 20.7 & 38.2 \\
\hline Zygnemataceae (U) & & 4.97 & & 8.59 & & 28.7 & & 13.3 \\
\hline Cyanophyceae & 4.87 & 5.09 & 4.43 & 14.06 & & 9.15 & 0.02 & 4.52 \\
\hline Oedogoniophyceae & 3.19 & 30.4 & 18.7 & 3.01 & & 0.13 & 0.7 & \\
\hline Bacillariophyceae & 1.67 & 17.1 & 0.24 & 25.23 & & 5.62 & & 4.55 \\
\hline Detritus & 45.2 & 23.8 & 14.2 & 5.77 & 1.02 & 39.8 & 15.2 & 34.1 \\
\hline Number of stomachs & 50 & 50 & 45 & 50 & 25 & 50 & 50 & 50 \\
\hline
\end{tabular}

Tab. II. Mean values \pm standard deviation (SD) of the relative condition factor (Kn); values of the Mann-Whitney U test and respective p-value.

\begin{tabular}{|c|c|c|c|c|}
\hline Species/ lagoons & Lagoon A & Lagoon B & \multicolumn{2}{|c|}{ Mann-Whitney } \\
\hline & $\mathrm{Kn} \pm \mathrm{DP}$ & $\mathrm{Kn} \pm \mathrm{DP}$ & $\mathrm{U}$ & $\mathrm{p}$ \\
\hline Hyphessobrycon eques & $1.01 \pm 0.12$ & $1.01 \pm 0.11$ & 1466.0 & 0.88 \\
\hline Odontostilbe pequira & $1.00 \pm 0.10$ & $1.01 \pm 0.16$ & 4416.0 & 0.57 \\
\hline Psellogrammus kennedyi & $1.01 \pm 0.11$ & $1.02 \pm 0.22$ & 1717.0 & 0.19 \\
\hline Serrapinnus calliurus & $1.02 \pm 0.19$ & $1.01 \pm 0.15$ & 5709.0 & 0.83 \\
\hline
\end{tabular}

fishes, feed, in general, in an opportunistic (or generalistic) way (Pelicice \& Agostinho, 2006). They show no clear morphological adaptation for food intake (CRIPPA et al., 2009).
In this study, the species have consumed primarily food of autochthonous origin (benthic), which can be related to the low water period at which the sampling was made, when little allochthonous material enters the system, and the 
water level is extremely low. CRIPPA et al. (2009) examined small characideans in the Upper Paraná River floodplain and report that the year at which the fish were collected was characterized as dry, which might have contributed to the small importance of terrestrial invertebrates for the diet of the fish species studied.

Spatial variations in diet were more evident when the species altered their feeding habits according to the lagoon. Hence, H. eques and $P$. kennedyi were detritivorous/ invertivorous and algivorous/invertivorous in the lagoons A and $\mathrm{B}$, respectively. Despite this observation, $H$. eques also consumed fish scales in the lagoon A, almost at the same proportion as detritus, a very nutritious food (PETERSON \& WINEMILLER, 1997) and abundant in the bottom, comparable to chironomids, consumed in the lagoon B. Thus, from an energetic point of view, this dietary change does not justify changes in nutritional status of this species, because, anyway, the population consumed a food high in both protein and energy, according to Bowen et al. (1995). Other studies on $H$. eques also registered the preference for food of animal origin (CASatti et al., 2003; Pelicice \& Agostinho, 2006; CRIPPA et al., 2009). On the other hand, for P. kennedyi that changed the diet from filamentous algae to chironomids, items with large difference in energy content (BowEN et al., 1995), the nutritional status was one of the best among the species studied. In this case, it can be inferred that the species has physiological adaptations that allow to obtain the maximum energy from food, even if it has low nutritional value, such as plant tissues, or that fish can compensate for the consumption of low nutritional food by increasing the consumption rate (Bowen et al., 1995). Such variation in diet quality and frequency of feeding exists particularly for generalists fishes, which are able to exploit a wide range of resources (YEAGER et al., 2014). This compensatory feeding strategy has been demonstrated for many taxa when environmental conditions limit the availability of high quality forage (TAILLON et al., 2006; Yeager et al., 2014). Apparently, P. kennedyi seems to have the same strategy in other environments, since XIMENES et al. (2011) classified the species as herbivorous in ten marginal lagoons of the Cuiabá River, MG, while RESENDE et al. (2000), considered it as zooplanktivorous in the Miranda River floodplain, MS.

Odontostilbe pequira and $S$. calliurus did not change their main food between the lagoons; they always consumed a mixture of detritus and unicellular and filamentous algae. The first species was considered benthivorous, and the second, omnivorous by XIMENES et al. (2011) and algivorous by ALVES et al. (2011). Despite the low nutritional value of the food, these species showed no differences in the condition factor, showing close values, regardless of the lagoon. The reason attributed to $P$. kennedyi may be applied to these two species.

In short, the occurrence of spatial variations in the diet caused no changes in the relative condition factor, suggesting that the species analyzed were not affected by possible changes in the supply of resources between lagoons. According Futuyma \& Moreno, (1988) species able to consume lower-quality resources when these vary greatly through time or space, may allow fitness to be maintened. Although aquatic invertebrates have high protein and energy content, algae represented the most nutritious source among primary producers in freshwater environments. They have high levels of protein and energy besides secondary metabolites that can act as antioxidants, and antibiotics (YURKOWSKI \& TABACHEK, 1979; Bowen et al., 1995; MišUrcové et al., 2010). Also, an experiment pointed out that an increase in the ingestion rate compensates for the consumption of reduced energy items (Bowen et al., 1995). Algae and detritus are especially abundant food in floodplain environments, which requires little energy for search and consumption, whereas aquatic invertebrates, despite their abundance, are items that require more energy for search. Thus, the similar values of the condition factor, regardless of the food source, are related to a balance between food availability and energy expenditure for consumption. Therefore, regardless of the resource consumed, these have met the metabolic needs of the fish in the studied lagoons, with positive effects on the fitness of these populations. However, this study showed effects of short-time between diet and body condition. Future research should consider systematic collection of long-term and stable isotopic analysis to understand the role of feeding plasticity on body condition in fish populations.

Acknowledgements. We express our gratitude to Nupélia (Núcleo de Pesquisas em Limnologia, Ictiologia e Aquicultura) for financial and logistical support. To CNPq (Conselho Nacional de Desenvolvimento Científico e Tecnológico) for grants to the two last authors (Proc. 302693/2013-0; 304040/2013-14) and for financial support to the SISBIOTA project (Proc. 563243/2010-4).

\section{REFERENCES}

Alves, G. H. Z. A.; Tófoli, R. M.; Novakowski, G. C. \& Hahn, N. S. 2011. Food partitioning between sympatric species of Serrapinnus (Osteichthyes, Cheirodontinae) in a tropical stream. Acta Scientiarum, Biological Sciences 33:153-159.

Barreto, A. P. \& Aranha, J. M. R. 2006. Alimentação de quatro espécies de Characiformes de um riacho da Floresta Atlântica, Guaraqueçaba, Paraná, Brasil. Revista Brasileira de Zoologia 23:779-788.

Bowen, S. H.; Lutz, E. V. \& Ahlgren, M. O. 1995. Dietary protein and energy as determinants of food quality: Trophic strategies compared. Ecology 76:899-907.

Britski, H. A.; Silimon, K. Z. S. \& Lopes, B. S. 2007. Peixes do Pantanal. Brasília, EMBRAPA. 230p.

Brown, J. H. 1995. Macroecology. University of Chicago Press, Chicago. 269p.

Carvalho, L. N. \& Del-Claro, K. 2004. Effects of predation pressure on the feeding behavior of the serpa tetra Hyphessobrycon eques (Ostariophysi, Characidae). Acta Ethologica 7:89-93.

Casatti, L.; Mendes, H. F. \& Ferreira, A. M. 2003. Aquatic macrophytes as feeding site for small fishes in the Rosana Reservoir, Paranapanema River, Southeastern Brazil. Brazilian Journal of Biology 63:213-222.

CorrêA, C. E.; Hahn, N. S. \& Delariva, R. L. 2009. Extreme trophic segregation between sympatric fish species: the case of small sized body Aphyocharax in the Brazilian Pantanal. Hydrobiologia 635:57-65.

Crippa, V.; Hahn, N. S. \& Fugi, R. 2009. Food resource used by smallsized fish in macrophyte patches in ponds of the upper Paraná river floodplain. Acta Scientiarum, Biological Sciences 31:119-125.

Cruz-Rivera, E. \& Hay, M. E. 2000. Can quantity replace quality? Food choice, compensatory feeding, and fitness of marine mesograzers. Ecology 81:201-219. 
Dias, T. S. \& Fialho, C. B. 2009. Biologia alimentar de quatro espécies simpátricas de Cheirodontinae (Characiformes, Characidae) do rio Ceará Mirim, Rio Grande do Norte. Iheringia, Série Zoologia 99:242-248.

EMBRAPA, 1991. Avaliação da contaminação ambiental da bacia hidrográfica do rio Miranda. Corumbá, EMBRAPA Pantanal. 174p.

Ferreira, A.; Paula, F. R. P.; Ferraz, S. F. B.; Gerhard, P.; Kashiwaqui, E. A. L.; Cyrino, J. E. P. \& Martinelli, L. A. 2012. Riparian coverage affects diets of characids in Neotropical streams. Ecology Freshwater Fish 21:12-22.

Futuyma, D. J. \& Moreno, G. 1988. The evolution of ecological specialization. Annual Review of Ecology and Systematics 19:207233.

Gerking, S. D. 1994. Feeding Ecology of Fish. San Diego, Academic Press. 416p.

Hahn, N. S.; Andrian, I. F.; Fugi, R. \& Almeida, V. L. L. 1997. Ecologia trófica. In: Vazzoler, A.E.A.M.; Agostinho, A. A. \& Hahn, N.S. A planície de inundação do alto rio Paraná: aspectos físicos, biológicos e socioeconômicos. Eduem, Maringá. 460p.

Hellawell, J. M. \& ABel, R. 1971. A rapid volumetric method for the analysis of the food of fishes. Journal of Fish Biology 3:29-37.

HysLOP, E. J. 1980. Stomach contents analysis - a review of methods and their applications. Journal of Fish Biology 17:411-429.

KaWAKami, E. \& VAzzoler, G. 1980. Método gráfico e estimativa de índice alimentar aplicado no estudo de alimentação de peixes. Boletim do Instituto Oceanográfico 29:205-207.

Le Cren, E. D. 1951. The Length-weight relationship and seasonal cycle in gonad weight and conditions in the perch Perca fluviatilis. Journal of Animal Ecology 20:201-19.

Lowe-MCConnell, R. H. 1999. Estudos ecológicos de comunidades de peixes tropicais. São Paulo, Edusp. 535p.

Manna, L. R.; Rezende, C. F. \& Mazzoni, R. 2012. Plasticity in the diet of Astyanax taeniatus in a coastal stream from south-east Brazil. Brazilian Journal of Biology 72:919-928.

McCune, B. \& MefFord, M. J. 1999. PC-ORD: Multivariate Analysis of Ecological Data (Version 4). Gleneden Beach, MJM Software Design.

Mišurcová, L.; Kráčmar, S.; Klejdus, B. \& VAceK., J. 2010. Nitrogen content, dietary fiber, and digestibility in algal food products. Czech Journal of Food Science 28:27-35.

Pelicice, F. M. \& Agostinho, A. A. 2006. Feeding ecology of fishes associated with Egeria spp. patches in a tropical reservoir, Brazil. Ecology of Freshwater Fish 15:10-19.

Peterson, C. C. \& Winemiller, K. O. 1997. Ontogenetic diet shifts and scale-eating in Roeboides dayi, a Neotropical characid. Environmental Biology of Fishes 49:111-118.
Resende, E. K.; Pereira, R.; Almeida, V. L. L. \& Silva, A. G. 2000. Peixes insetívoros e zooplanctófagos da planície inundável do rio Miranda, Mato Grosso do Sul, Brasil. Boletim de Pesquisa EMBRAPA Pantanal 17:1-42.

Schneider, M.; Aquino, P. P. U.; Silva, M. J. M. \& Fonseca, C. P. 2011. Trophic structure of a fish community in Bananal stream subbasin in Brasília National Park, Cerrado biome (Brazilian Savanna), DF. Neotropical Ichthyology 9:579-592.

SpecziÁr, A. \& Erós, T. 2014. Dietary variability in fishes: the roles of taxonomic, spatial, temporal and ontogenetic factors. Hydrobiologia 724:109-125.

Statsoft, InC. Statistica (data analysis software system). 2005.Version 7.1 for Windows. Tulsa: Statsoft. Inc.

Stephens, D. W. \& Krebs, J. R. 1986. Foraging Theory. Princeton, Princeton University Press. 247p.

Taillon, J.; Sauve, D. G. \& Cote, S. D. 2006. The effects of decreasing winter diet quality on foraging behavior and life-history traits of whitetailed deer fawns. Journal of Wildlife Management 70:1445-1454.

Tófoli, R. M.; Hahn, N. S.; Alves, G. H. Z. \& Novakowski, G. C. 2010 Uso do alimento por duas espécies simpátricas de Moenkhausia (Characiformes, Characidae), em um riacho Neotropical, Brasil. Iheringia, Série Zoologia 100:201-206.

VAZzoler, A. E. A. M. 1996. Biologia da reprodução de peixes teleósteos: teoria e prática. Eduem, Maringá. 169p.

WolfF, L. L.; Carniatto, N. \& Hahn, N. S. 2013. Longitudinal use of feeding resources and distribution of fish trophic guilds in a coastal Atlantic stream, southern Brazil. Neotropical Ichthyology 11:375-386.

Wootton, R. J. 1990. Ecology of Teleost Fishes. New York, Chapman and Hall. 386p.

Ximenes, L. Q. L.; Mateus, L. A. F. \& Penha, J. M. F. 2011. Variação temporal e espacial na composição de guildas alimentares da ictiofauna em lagoas marginais do Rio Cuiabá, Pantanal Norte. Biota Neotropical 11:206-215.

Yeager, L. A.; Layman, C. A. \& Hammerschlag-Peyer, C. M. 2014. Diet variation of a generalist fish predator, grey snapper Lutjanus griseus, across an estuarine gradient: trade-offs of quantity for quality? Journal of Fish Biology 85:264-277.

Yurkowski, M. \& TABACheK, J. L. 1979. Proximate and amino acid composition of some natural fish foods. Proceedings of the World Symposium on Finfish Nutrition and Fishfeed Technology 1:435-448.

Zimmerman, G. M.; Goetz, H. \& Mielke, P. W. 1985. Use of an improved statistical method for group comparisons to study effects of prairie fire. Ecology 66:606-611. 